\title{
UPAYA SOCIAL MARKETING GUNA MENINGKATKAN ADHERENCE MINUM OBAT PASIEN UPIPI RSUD DR. SOETOMO SURABAYA
}

\author{
Lilis Masyfufah A.S.* \\ *Dosen D3 Rekam Medik dan Informasi Kesehatan STIKES Yayasan RS Dr. Soetomo \\ Surabaya \\ Email: lilismasyfufahas@gmail.com
}

\begin{abstract}
ABSTRAK
HIV adalah infeksi yang disebabkan oleh virus yang menyerang kekebalan tubuh manusia. ARV Therapy (ART) harus dilakukan secara rutin dan seumur hidup. Tantangan utama ART yaitu membutuhkan adherence tinggi. Di UPIPI RSUD Dr. Soetomo, persentase pasien dengan adherence tinggi, dari 2010 - Mei 2014 rerata pertumbuhannya rendah, sebaliknya, pasien dengan adherence rendah, semakin meningkat pertumbuhannya. Salah satu bentuk penyadaran pasien tentang pentingnya adherence adalah melalui social marketing. Tujuan dari social marketing adalah mempengaruhi konsumen untuk mengubah perilaku demi meningkatkan kesehatan. Oleh karena itu, tujuan dari penelitian ini adalah menyusun rekomendasi social marketing guna peningkatan adherence pasien.

Metode penelitian pada penelitian ini adalah cross sectional, observasional dengan diskriptif analitik. Hasil dari penelitian menunjukkan faktor karakteristik dan faktor IMB Model yang berhubungan dengan tingkat adherence pasien adalah keikutsertaan dalam organisasi, keterjangkauan biaya pengobatan, informasi tentang terapi ARV, yang didalamnya terdapat informasi régimen, manfaat $A R V$, cara kerja obat $A R V$, dan pentingnya adherence, serta motivasi minum obat ARV dari orang terdekat sekitar pasien.

Berdasarkan data tersebut, maka disusunlah rencana social marketing yang bertema hidup berkualitas dengan minum ARV tuntas. Kegiatannya meliputi menyelenggarakan penyuluhan, menginformasikan tentang manfaat obat ARV dan cara kerja obat ARV dengan menggunakan metode konseling, mengoptimalkan LSM untuk melakukan pendampingan, melalui internet yaitu website dan media sosial rumah sakit, dan leaflet. Selain itu membiasakan pasien minum obat secara rutin dengan selalu mengingat memasukkan obat ARV ke dalam kotak obat dan membentuk peer group yang berfungsi untuk saling mengingatkan dan memberikan motivasi antar sesama pasien.
\end{abstract}

Kata kunci: Peningkatan adherence, social marketing, IMB Model

\section{ABSTRACK}

$H I V$ is an infection caused by a virus that attacks the human immune system. ARV Therapy (ART) should be done regularly and lifetime. ART major challenge that requires a higher adherence. The UPIPI of Dr. Soetomo Hospital, the percentage of patients with high adherence, from 2010 - May 2014 mean low growth, in contrast, patients with low adherence, increasing growth. One form of patient awareness about the importance of adherence is through social marketing. The purpose of this study is to develop a social marketing recommendations in order to improve patient adherence. The research method is cross-sectional, observational analytic descriptive. Results of the study indicate factor IMB model characteristics and factors associated with patient adherence level is participation in the organization, affordability of treatment, information about antiretroviral therapy, in 
which there is information regimens, the benefits of antiretroviral drugs, the workings of antiretroviral drugs, and the importance of adherence, as well as motivation taking ARV drugs from the nearest vicinity of the patient. Based on these data, then drafted a social marketing plan on the theme of quality of life by taking drugs completely. Its activities include organizing counseling, informing about the benefits of antiretroviral drugs and how $A R V$ drugs work by using the method of counseling, optimize NGOs to provide guidance, via the internet, namely social media websites and hospitals, and leaflets. In addition to familiarize the patient to take medication regularly to always remember entering ARV drugs in the medicine cabinet and form a peer group that serves to remind each other and provide motivation among fellow patients.

Keywords: Improved adherence, social marketing, IMB Model

\section{PENDAHULUAN}

Human Immunodeficiency Virus (HIV) merupakan infeksi yang disebabkan oleh virus yang menyerang kekebalan tubuh manusia. WHO menjadikan penurunan angka kesakitan dan kematian HIV AIDS sebagai salah satu target Millenium Development Goals (MDGs). Untuk melaksanakan tugas tersebut, RSUD Dr. Soetomo membentuk Tim Medik AIDS yang dalam pelaksanaannya dikerjakan oleh Unit Intermediate Penyakit Infeksi (UPIPI). Setelah diagnosis tegak, pasien dialihkan ke layanan CST untuk mendapatkan pelayanan klinis berupa penyembembuhan infeksi tumpangan, pengecekan kondisi tubuh, dan pengobatan HIV dengan terapi obat ARV. ARV Therapy (ART) harus dilakukan secara rutin dan seumur hidup. Tantangan utama ART yaitu masalah kepatuhan (adherence) yang sangat tinggi dan akses layanan jika berada di daerah terpencil (Dinkes Jatim, 2013).

Angka kunjungan pasien ART semakin meningkat. Namun, adherence pasien ART terjadi penurunan (rerata 2,31\%). Jika diuraikan kedalam tingkata adherence-nya, persentase pasien dengan adherence tinggi, yaitu $\geq 95 \%$, semakin menurun dari 2010 - Mei 2014 dengan rerata pertumbuhan (growth) 11,13\%. Namun sebaliknya, pasien dengan adherence rendah, yaitu $>80-95 \%$ dan $\leq 80 \%$, semakin meningkat dengan rerata growth 190,87\%, dan 186,94\%. Jika peningkatan jumlah pasien dengan adherence rendah tersebut tidak segera ditangani, maka akan meningkatkan pasien gagal of follow up (GFU), yang sampai dengan Mei 2014, rerata growth pasien GFU adalah 56,06\%.

Salah satu hal yang menentukan kepatuhan pasien dalam tatalaksana ART adalah adanya konseling pra ART. Selain itu, yang termasuk bentuk pemberian informasi kepada pasien adalah melalui pemasaran sosial (social marketing). Tujuan dari social marketing adalah mempengaruhi konsumen untuk mengubah perilaku untuk meningkatkan kesehatan. Dalam kasus HIV AIDS adanya social marketing sangat penting, karena diperlukan upaya penyadaran pasien HIV AIDS terkait pentingnya adherence, sehingga manfaat dari ARV dapat tercapai secara optimal. Social marketing terbukti memberikan banyak manfaat, misalnya program keluarga berencana (KB) dan pemakaian jarum suntik steril.

\section{Tujuan}

Tujuan dari penelitian ini adalah menyusun social marketing guna meningkatkan adherence pasien UPIPI RSUD Dr. Soetomo Surabaya. Penelitian ini menggunakan pendekatan faktor yang mempengaruhi adherence seseorang yang meliputi analisis karaktersitik dan teori information, motivation, and behavioral skills (IMB) Model (Fisher, Fisher, dan 
Harman, 2006). Kesimpulan analisis tersebut digunakan sebagai pertimbangan penyusunan rencana social marketing guna meningkatkan adherence pasien dengan menggunakan tahap dari teori Cheng, Kotler, dan Lee (2008) dan Weinreich (2006).

\section{Metode}

Jenis penelitian ini adalah observasional dengan desain penelitian deskriptif analitik, yaitu penggabungan análisis dari kuantitatif dan kualitatif. Rancang bangun penelitian ini adalah cross sectional. Tahap pertama adalah penelitian kuantitatif yang digunakan untuk menentukan faktor yang mempengaruhi adherence pasien jika dikaji dari karakteristik pasien dan pendekatan teori IMB Model. Tahap berikutnya adalah penelitian kualitatif karena dilakukan eksplorasi análisis induktif untuk menggambarkan secara mendalam dan ringkas kondisi faktor rumah sakit. Data ini digunakan untuk mengkaji faktor rumah sakit yang mendukung program HIV AIDS di UPIPI RSUD Dr. Seotomo Surabaya. Kedua hasil tersebut digunakan sebagai landasan menyusun social marketing untuk meningkatkan adherence. Populasi pada penelitian ini adalah pasien UPIPI yang sudah melakukan ART. Populasi pasien rawat jalan UPIPI merupakan populasi infinit, maka perhitungan besar sampel dilakukan dengan metode estimasi proporsi dan teknik pengambilan sampel dengan purposive sampling.

\section{Hasil}

Hasil dari penelitian ini adalah sebagaimana Tabel 1 berikut ini.

Tabel 1 Hasil dan Penggunaan Data Hasil Penelitian dalam Penyusunan Social Marketing Guna Peningkatan Adherence Pasien UPIPI RSUD Dr. Soetomo Surabaya Tahun 2015

\begin{tabular}{|c|c|c|c|}
\hline No & Variabel & Hasil Penelitin & $\begin{array}{c}\text { Rencana } \\
\text { Pemakaian } \\
\text { dalam Social } \\
\text { Marketing pada } \\
\text { Tahap } \\
\end{array}$ \\
\hline 1 & Umur & $\begin{array}{l}88,3 \% \text { usia produktif; } 25-49 \\
\text { tahun }\end{array}$ & \multirow[t]{5}{*}{$\begin{array}{l}\text { Analisis situasi } \\
\text { Target audience }\end{array}$} \\
\hline 2 & Jenis kelamin & $\begin{array}{l}\text { Masing-masing } 50 \% ; \quad \text { laki-laki } \\
\text { dan perempuan }\end{array}$ & \\
\hline 3 & Pendapatan & $\begin{array}{l}58,3 \% \text { pendapatan cukup; Rp } \\
1.000 .000,--3.000 .000,-\end{array}$ & \\
\hline 4 & Pendidikan & $\begin{array}{l}63,3 \% \text { cukup tinggi; SMA atau } \\
\text { sederajat }\end{array}$ & \\
\hline 5 & $\begin{array}{l}\text { Keanggotaan dalam suatu } \\
\text { kelompok }\end{array}$ & $\begin{array}{l}66,7 \% \text { tidak mengikuti organisasi } \\
\text { kemasyarakatan }\end{array}$ & \\
\hline 6 & Penginisiasi ART & $\begin{array}{l}46,7 \% \text { dikonseling oleh perawat } \\
\text { atau konselor } \\
38,3 \% \text { dikonseling dokter } \\
10 \% \text { dikonseling oleh apoteker } \\
\text { dan LSM } \\
5 \% \text { tidak dikonseling }\end{array}$ & Analisis situasi \\
\hline 7 & Isu sosial & $\begin{array}{l}\text { Alasan tidak minum obat adalah } \\
51,7 \% \text { lupa, } 10 \% \text { bosan dan } 3,3 \% \\
\text { malu selalu minum obat, } 1,7 \% \\
\text { merasa sehat, dan } 1,7 \% \text { antri } \\
\text { lama }\end{array}$ & $\begin{array}{l}\text { Potitioning } \\
\text { Faktor yang } \\
\text { mempengaruhi } \\
\text { perilaku adopsi }\end{array}$ \\
\hline
\end{tabular}




\begin{tabular}{|c|c|c|c|}
\hline No & Variabel & Hasil Penelitin & $\begin{array}{c}\text { Rencana } \\
\text { Pemakaian } \\
\text { dalam Social } \\
\text { Marketing pada } \\
\text { Tahap } \\
\end{array}$ \\
\hline 8 & Keterjangkauan UPIPI & $\begin{array}{l}\text { 55\% keberadaan UPIPI cukup } \\
\text { terjangkau }\end{array}$ & Analisis situasi \\
\hline 9 & $\begin{array}{l}\text { Keterjangkauan biaya } \\
\text { pengobatan }\end{array}$ & $\begin{array}{l}66,7 \% \text { biaya pengobatan di UPIPI } \\
\text { cukup terjangkau }\end{array}$ & Analisis situasi \\
\hline 10 & $\begin{array}{l}\text { Media informasi } \\
\text { a. Jam layanan di faskes } \\
\text { b. Aktivitas } \\
\text { menunggu } \\
\text { c. Media informasi yang } \\
\text { sering diakses } \\
\text { d. Benda pengingat minum } \\
\text { obat }\end{array}$ & $\begin{array}{l}80 \% \text { menghabiskan waktu } 2-5 \\
\text { jam di UPIPI } \\
75 \% \text { berbincang-bincang dengan } \\
\text { sesama pasien } \\
18,3 \% \text { bermain hp } \\
5 \% \text {; membaca koran atau majalah } \\
1,7 \% \text { menonton TV } \\
35 \% \text { dari kegiatan penyuluhan } \\
23,3 \% \text { dari internet } \\
18,3 \% \text { dari program } \mathrm{TV} \\
11,7 \% \text { dari Leaflet } \\
8,3 \% \text { Koran atau majalah } \\
45 \% \text { kotak obat } \\
21,7 \% \text { tas } \\
10 \% \text { gelas } \\
1,7 \% \text { bolpoin, notes, atau pin }\end{array}$ & Bauran pemasaran \\
\hline 11 & $\begin{array}{l}\text { Informasi adherence } \\
\text { a. Informasi regimen } \\
\text { b. Informasi manfaat ARV } \\
\text { c. Informasi efek samping } \\
\text { obat ARV } \\
\text { d. Informasi cara kerja } \\
\text { obat ARV } \\
\text { e. Informasi pentingnya } \\
\text { adherence }\end{array}$ & $\begin{array}{l}61,7 \% \text { sedang } \\
66,7 \% \text { tinggi } \\
66,7 \% \text { sedang } \\
58,3 \% \text { sedang } \\
63,3 \% \text { sedang } \\
\text { 45,0\% rendah }\end{array}$ & Analisis situasi \\
\hline 12 & $\begin{array}{l}\text { Motivasi adherence } \\
\text { a. Kepercayaan terhadap } \\
\text { ARV } \\
\text { b. Harapan mengkonsumsi } \\
\text { ARV } \\
\text { c. Persepsi orang terdekat } \\
\text { disekitar pasien tentang } \\
\text { adherence } \\
\text { d. Motivasi dari orang } \\
\text { terdekat disekitar pasien } \\
\text { untuk minum obat rutin }\end{array}$ & $\begin{array}{l}61,7 \% \text { sedang } \\
68,3 \% \text { sedang } \\
60 \% \text { sedang } \\
\begin{array}{l}\text { Masing-masing } 46,7 \% \text { rendah } \\
\text { dan sedang }\end{array} \\
55 \% \text { tinggi }\end{array}$ & Analisis situasi \\
\hline 13 & $\begin{array}{l}\text { Behavioral skills } \\
\text { a. Manajemen ARV } \\
\text { b. Meminimalisir efek } \\
\text { samping AR }\end{array}$ & $\begin{array}{l}56,7 \% \text { sedang } \\
56,7 \% \text { sedang } \\
66,7 \% \text { sedang }\end{array}$ & Analisis situasi \\
\hline
\end{tabular}




\begin{tabular}{|c|c|c|c|}
\hline No & Variabel & Hasil Penelitin & $\begin{array}{c}\text { Rencana } \\
\text { Pemakaian } \\
\text { dalam Social } \\
\text { Marketing pada } \\
\text { Tahap }\end{array}$ \\
\hline 14 & $\begin{array}{l}\text { Perilaku adherence } \\
\text { a. Ketepatan waktu } \\
\text { kunjung berikutnya } \\
\text { b. Ketepatan dosis } \\
\text { c. Sisa butir obat } \\
\text { sebelumnya }\end{array}$ & $\begin{array}{l}68,3 \% \text { adherence tinggi } \\
28,3 \% \text { adherence sedang } \\
3,3 \% \text { adherence rendah } \\
16,7 \%>7 \text { hari dari seharusnya } \\
15 \% 3-7 \text { hari dari seharusnya } \\
68,3 \%<3 \text { hari dari seharusnya } \\
15 \% \text { sesuai dosis } \\
1,7 \% \text { tidak semua sesuai dosis } \\
83,3 \% \text { sesuai dosis } \\
3,3 \% \text { sisa }>12 \text { butir } \\
13,3 \% \text { sisa } 3-12 \text { butir } \\
83,3 \% \text { tidak sisa atau sisa }<3 \\
\text { butir }\end{array}$ & $\begin{array}{l}\text { Analisis situasi } \\
\text { Target audience } \\
\text { Faktor yang } \\
\text { mempengaruhi } \\
\text { perilaku adopsi }\end{array}$ \\
\hline 15 & $\begin{array}{l}\text { Hubungan karakteristik } \\
\text { dan faktor IMB Model } \\
\text { terhadap tingkat adherence } \\
\text { pasien }\end{array}$ & $\begin{array}{l}\text { Keikutsertaan pasien dalam } \\
\text { organisasi kemasyarakatan (sig. } \\
0,019 \text { ) } \\
\text { Keterjangkauan biaya berobat di } \\
\text { UPIPI (sig. 0,010) } \\
\text { Informasi tentang terapi ARV } \\
\text { (sig. 0,000) } \\
\text { Informasi tentang rejimen ARV } \\
\text { (sig. 0,000) } \\
\text { Informasi tentang manfaat ARV } \\
\text { (sig. 0,000) } \\
\text { Informasi tentang cara kerja ARV } \\
\text { (sig. 0,000) } \\
\text { Informasi tentang pentingnya } \\
\text { adherence ARV (sig. 0,000) } \\
\text { Motivasi minum obat ARV rutin } \\
\text { dari orang terdekat sekitar (sig. } \\
0,041 \text { ) }\end{array}$ & $\begin{array}{ll}\text { Tujuan } & \text { social } \\
\text { marketing } & \end{array}$ \\
\hline 16 & $\begin{array}{l}\text { Pengaruh karakteristik dan } \\
\text { faktor IMB Model } \\
\text { terhadap tingkat adherence } \\
\text { pasien }\end{array}$ & $\begin{array}{l}\text { Informasi manfaat ARV (sig. } \\
0,000 \text { ) } \\
\text { Informasi cara kerja ARV (sig. } \\
0,000 \text { ) } \\
\text { Motivasi minum obat ARV rutin } \\
\text { dari orang terdekat sekitar (sig. } \\
0,000 \text { ) }\end{array}$ & $\begin{array}{l}\text { Faktor yang } \\
\text { mempengaruhi } \\
\text { perilaku adopsi }\end{array}$ \\
\hline 17 & $\begin{array}{l}\text { Kebijakan HIV (kategori } \\
\text { baik) }\end{array}$ & $\begin{array}{l}\text { 1. Mempunyai pelayanan yang } \\
\text { komprehensif, tetapi middle } \\
\text { manager tidak paham } \\
\text { 2. Tarif sesuai Perda dan SK } \\
\text { Direktur serta ada yang } \\
\text { ditentukan Tim Medik AIDS } \\
\text { dan terjangkau oleh pasien }\end{array}$ & $\begin{array}{l}\text { Analisis situasi } \\
\text { Bauran pemasaran }\end{array}$ \\
\hline
\end{tabular}




\begin{tabular}{|c|c|c|c|}
\hline No & Variabel & Hasil Penelitin & $\begin{array}{c}\text { Rencana } \\
\text { Pemakaian } \\
\text { dalam Social } \\
\text { Marketing pada } \\
\text { Tahap }\end{array}$ \\
\hline & & $\begin{array}{l}\text { 3. Dana operasional dari } \\
\text { pemerintah, walaupunn ada } \\
\text { dari NGO tetapi dianggap } \\
\text { tidak ada karena bersifat hibah } \\
\text { dan tidak selalu ada } \\
\text { 4. Bagian khusus social } \\
\text { marketing ada pada PKRS, } \\
\text { namun tidak ada dana khusus } \\
\text { untuk pengembangan social } \\
\text { marketing }\end{array}$ & \\
\hline 18 & $\begin{array}{l}\text { Evaluasi pelayanan pasien } \\
\text { (kategori baik) }\end{array}$ & $\begin{array}{l}\text { 1. Terdapat laporan rutin; } \\
\text { laporan bulanan, IKM, SPM; } \\
\text { IKM agregat menunjukkan } \\
\text { angka 77\%; cukup puas } \\
\text { 2. Terdapat laporan tidak rutin; } \\
\text { temuan penelitian dan } \\
\text { komplain pasien } \\
\text { 3. Adanya upaya perbaikan dari } \\
\text { waktu ke waktu }\end{array}$ & Analisis situasi \\
\hline 19 & $\begin{array}{ll}\text { Persepsi } & \text { terhadap } \\
\text { adherence } & \text { (kategori } \\
\text { sedang) } & \end{array}$ & $\begin{array}{l}\text { 1. Adherence sangat penting } \\
\text { untuk keberhasilan } \\
\text { pengobatan dan program } \\
\text { 2. Pemahaman manajemen } \\
\text { tentang faktor yang } \\
\text { mempengaruhi adherence } \\
\text { baik } \\
\text { 3. Bagian khusus peningkatan } \\
\text { adherence tidak ada karena } \\
\text { semua elemen turut } \\
\text { bertanggung jawab } \\
\text { 4. Ada usaha peningkatan } \\
\text { adherence, tapi rencana belum } \\
\text { berjalan }\end{array}$ & Analisis situasi \\
\hline 20 & $\begin{array}{l}\text { Stigma dan diskriminasi } \\
\text { petugas (kategori baik) }\end{array}$ & $\begin{array}{l}\text { 1. Pelayanan di UPIPI sesuai } \\
\text { dengan pedoman dan panduan } \\
\text { nasional } \\
\text { 2. Stigma dan diskriminasi ada } \\
\text { di luar UPIPI di RS, tetapi } \\
\text { tidak di UPIPI sendiri } \\
\end{array}$ & Analisis situasi \\
\hline 21 & $\begin{array}{l}\text { Pelaksanaan konseling pra } \\
\text { ART (kategori rendah) }\end{array}$ & $\begin{array}{llr}\text { 1. } & \text { Konseling ART tidak selalu } \\
\text { dilakukan di UPIPI } & \\
\text { 2. } & \text { Pelaksanaan } & \text { konseling } \\
& \text { optimalnya 20-30 menit, } \\
\text { menurut petugas Poli UPIPi }\end{array}$ & Analisis situasi \\
\hline
\end{tabular}




\begin{tabular}{|c|c|c|c|}
\hline No & Variabel & Hasil Penelitin & $\begin{array}{c}\text { Rencana } \\
\text { Pemakaian } \\
\text { dalam Social } \\
\text { Marketing pada } \\
\text { Tahap }\end{array}$ \\
\hline & & $\begin{array}{l}\text { 3. Isi konseling harusnya } \\
\text { lengkap, tetapi di Poli tidak } \\
\text { lengkap, hanya tentang fek } \\
\text { samping } \\
\text { 4. Seharusnya ada konseling lain } \\
\text { selain VCT dan ART, tetapi } \\
\text { tidak dilakukan }\end{array}$ & \\
\hline 22 & $\begin{array}{lll}\text { Program } & \text { RS } & \text { yang } \\
\text { mendukung } & \text { program } & \text { HIV } \\
\text { AIDS } & & \end{array}$ & $\begin{array}{l}\text { Top manager memahami tentang } \\
\text { tugas RS yang harus melakukan } \\
\text { preventif, promotif, kuratif, dan } \\
\text { rehabilitatif, namun middle } \\
\text { manager tidak memahami hal } \\
\text { tersebut }\end{array}$ & Analisis situasi \\
\hline
\end{tabular}

Tabel 5.47 menunjukkan rangkuman hasil penelitian yang digunakan sebagai dasar penyusunan social marketing untuk peningkatan adherence pasien. Perencanaan social marketing yang disesuaikan dengan data hasil penelitian yang telah dilakukan, diharapkan dapat berhasil dan tepat guna sesuai tujuan program. Adapun dokumen rencana social marketing yang direkomendasikan, dibahas dalam sub bab berikutnya

Tabel 2 Perencanaan Social Marketing Guna Meningkatkan Adherence Pasien UPIPI RSUD Dr. Soetomo Surabaya Tahun 2015

\begin{tabular}{|c|l|l|}
\hline No. & \multicolumn{1}{|c|}{ Tahap } & \multicolumn{1}{c|}{ Keterangan } \\
\hline 1 & $\begin{array}{l}\text { Ide social } \\
\text { marketing }\end{array}$ & "Hidup berkualitas dengan minum ARV tuntas" \\
\hline 2 & Maksud ide & $\begin{array}{l}\text { Hidup ODHA akan lebih berkualitas, yaitu panjang umur, tidak } \\
\text { mudah sakit, CD4 tinggi, dan viral load tidak terdeteksi (sesuai } \\
\text { dengan manfaat ARV), jika ODHA minum ARV secara tuntas; } \\
\text { rutin sesuai dosis yang dianjurkan dan mengambil obat tepat } \\
\text { waktu, sehingga tidak ada obat tersisa atau kurang untuk satu } \\
\text { bulan. }\end{array}$ \\
\hline 3 & $\begin{array}{l}\text { Latar belakang } \\
\text { penyusunan } \\
\text { program social } \\
\text { marketing }\end{array}$ & $\begin{array}{l}\text { Tingginya tingkat pertumbuhan pasien dengan adherence rendah } \\
\text { (188,91\%) dibandingkan dengan adherence tinggi (11,36\%) } \\
\text { (perbandingan 1:16) }\end{array}$ \\
\cline { 2 - 5 } & $\begin{array}{l}\text { Tujuan program } \\
\text { social marketing }\end{array}$ & $\begin{array}{l}\text { Meningkatkan keberhasilan pengobatan ARV; mengurangi risiko } \\
\text { penularan HIV, menghambat perburukan infeksi tumpangan, } \\
\text { meningkatkan kualitas hidup penederita HIV, dan menurunkan } \\
\text { jumlah virus }\end{array}$ \\
\cline { 2 - 5 } & Fokus program & Meningkatkan kepatuhan minum obat (adherence) pasien HIV \\
\hline 4 & $\begin{array}{l}\text { Analisis situasi } \\
\text { Kekuatan }\end{array}$ & $\begin{array}{l}\text { 1. Pelayanan HIV sama dengan pelayanan yang } \\
\text { lain }\end{array}$ \\
& $\begin{array}{l}\text { 2. Terdapat evaluasi rutin bulanan terkait ARV, } \\
\text { sehingga termonitor rutin juga }\end{array}$ \\
\hline
\end{tabular}




\begin{tabular}{|c|c|c|c|}
\hline No. & Tahap & & Keterangan \\
\hline & & & $\begin{array}{l}\text { 3. Terdapat evaluasi rutin layanan, sehingga } \\
\text { kualitas layanan terjaga } \\
\text { 4. Adanya dukungan dari manajemen untuk upaya } \\
\text { perbaikan adherence } \\
\text { 5. Tidak ada stigma dan diskriminasi di Poli } \\
\text { UPIPI }\end{array}$ \\
\hline & & Kelemahan & $\begin{array}{l}\text { 1. Tidak ada program yang difokuskan untuk } \\
\text { social marketing } \\
\text { 2. Tidak ada dukungan khusus terkait } \\
\text { pengembangan social marketing kecuali sesuai } \\
\text { pada umumnya } \\
\text { 3. Evaluasi rutin terkait program HIV belum } \\
\text { begitu diperhatikan tindak lanjutnya } \\
\text { 4. Evaluasi rutin layanan tidak selalu dikerjakan } \\
\text { 5. Konseling ART tidak selalu dilakukan } \\
\text { 6. Petugas Poli UPIPI belum memahami tentang } \\
\text { konseling yang seharusnya wajib dilakukan } \\
\text { 7. Middle management belum memahami tentang } \\
\text { pelayanan HIV sepenuhnya dan program RS } \\
\text { yang mendukung program HIV }\end{array}$ \\
\hline & & Peluang & $\begin{array}{l}\text { 1. Pendapatan pasien cukup; antara Rp } \\
\text { 1.000.000,- - } 3.000 .000,- \\
\text { 2. Pendidikan pasien cukup tinggi; SMA } \\
\text { 3. Mayoritas pasien dikenseling oleh perawat atau } \\
\text { konselor } \\
\text { 4. Keterjangkauan faskes dan biaya pengobatan } \\
\text { cukup terjangkau } \\
\text { 5. Faktor informasi, motivasi, dan behavioral } \\
\text { skills pasien mayoritas kat. sedang }\end{array}$ \\
\hline & & Ancaman & $\begin{array}{l}\text { 1. Mayoritas pasien tidak tergabung dalam } \\
\text { kelompok dukungan sebaya } \\
\text { 2. Perawat yang melakukan konseling lengkap } \\
\text { hanya perawat senior } \\
\text { 3. Mayoritas pasien ODHA belum terbuka kepada } \\
\text { orang terdekat disekitarnya }\end{array}$ \\
\hline 5 & $\begin{array}{l}\text { Target audience } \\
\text { program social } \\
\text { marketing }\end{array}$ & \multicolumn{2}{|c|}{$\begin{array}{l}\text { Target primer: Pasien UPIPI RSUD Dr. Soetomo dengan tingkat } \\
\text { adherence sedang dan rendah (tingkat adherence } 2 \text { dan } 3) \text {. } \\
\text { Terutama pasien pada usia produktif }(25-49 \text { tahun), dengan } \\
\text { tingkat pendidikan menengah ke atas yaitu SMA, pendapatan } \\
\text { menengah; Rp } 1.000 .000,--3.000 .000,- \text {, dan tidak mengikuti } \\
\text { suatu organisasi tertentu. } \\
\text { Target skunder: Semua pasien UPIPI } \\
\text { Target tersier: Keluarga pasien UPIPI }\end{array}$} \\
\hline 6 & $\begin{array}{l}\text { Tujuan program: } \\
90 \% \text { pasien } \\
\text { memiliki } \\
\text { adherence tinggi } \\
(>95 \%) \text { pada } \\
\text { setiap bulannya }\end{array}$ & $\begin{array}{l}\text { Sasaran } \\
\text { program: } \\
\text { peningkatan } \\
\text { informasi } \\
\text { terapi ARV }\end{array}$ & $\begin{array}{l}\text { 1. Meningkatkan informasi pasien terkait regimen } \\
\text { ARV yang dikonsumsi } \\
\text { 2. Meningkatkan informasi pasien terkait manfaat } \\
\text { obat ARV } \\
\text { 3. Meningkatkan infromasi terkait cara kerja obat } \\
\text { ARV }\end{array}$ \\
\hline
\end{tabular}




\begin{tabular}{|c|c|c|}
\hline No. & Tahap & Keterangan \\
\hline & $\begin{array}{lr}\text { (Sesuai } & \text { Pedoman } \\
\text { RR } & \text { Kemenkes } \\
2014) & \\
\end{array}$ & $\begin{array}{l}\text { 4. Meningkatkan informasi tentang pentingnya } \\
\text { adherence dalam konsumsi obat ARV }\end{array}$ \\
\hline \multirow[t]{3}{*}{7} & \multicolumn{2}{|c|}{ Rencana kegiatan program social marketing } \\
\hline & $\begin{array}{l}\text { Bentuk kegiatan } \\
\text { program }\end{array}$ & $\begin{array}{l}\text { 1. Melakukan kampanye dalam bentuk penyuluhan untuk minum } \\
\text { ARV rutin dan tepat waktu oleh perawat UPIPI kepada pasien, } \\
\text { terutama pasien yang adherence-nya rendah pada bulan } \\
\text { tersebut. Penyuluhan dipilih karena sebanyak } 35 \% \text { pasien } \\
\text { mengaku mendapatkan informasi tentang kesehatan dari } \\
\text { penyuluhan. Hal ini didukung dengan kebijakan RSUD Dr. } \\
\text { Soetomo yang memiliki tim PKRS sebagai tim untuk } \\
\text { memberikan edukasi kepada pasien atau keluarga pasien. } \\
\text { 2. Menginformasikan tentang manfaat obat ARV dan cara kerja } \\
\text { obat ARV (karena dua hal tersebut merupakan faktor } \\
\text { informasi yang berpengaruh terhadap tingkat adherence } \\
\text { pasien), dengan menggunakan metode konseling mendalam } \\
\text { (bentuk lain dari penyuluhan), mengoptimalkan LSM untuk } \\
\text { melakukan pendampingan (karena ada <10\% pasien mengaku } \\
\text { mendapatkan konseling ART dari LSM), melalui internet yaitu } \\
\text { website dan media sosial rumah sakit (23,3\% pasien sering } \\
\text { mengkases internet untuk mencari informasi tentang } \\
\text { kesehatan), dan leaflet (11,7\% pasien sering mengakses media } \\
\text { informasi melalui leaflet) } \\
\text { 3. Membiasakan pasien minum obat secara rutin dengan selalu } \\
\text { mengingat memasukkan obat ARV ke dalam kotak obat. Hal } \\
\text { ini dilakukan karena } 45 \% \text { pasien mengaku bahwa benda yang } \\
\text { mengingatkan untuk minum obat adalah kotak obat. } \\
\text { 4. Membentuk peer group yang berfungsi untuk saling } \\
\text { mengingatkan dan memberikan motivasi antar sesama pasien. } \\
\text { Hal ini sesuai dengan hasil penelitian yang menyebutkan } \\
\text { bahwa } 75 \% \text { pasien mengaku berbincanng-bincang dengan } \\
\text { sesama pasien pada saat menunggu antrian kontrol. Hal ini } \\
\text { bisa diisi dengan topik tentang berbagi informasi tentang } \\
\text { terapi ARV. }\end{array}$ \\
\hline & $\begin{array}{l}\text { Persiapan } \\
\text { pelaksanaan } \\
\text { program }\end{array}$ & $\begin{array}{l}\text { 1. Memberikan pelatihan yang bersifat refreshing kepada petugas } \\
\text { Poli UPIPI, utamanya perawat, tentang konseling ART yang } \\
\text { baik dan benar, sehingga ilmu yang didapatkan bisa } \\
\text { diaplikasikan untuk konseling pasien dan juga penyuluhan. } \\
\text { Kegiatan ini bisa menggunakan dana dari RS yang } \\
\text { dialokasikan melalui diklat. } \\
\text { 2. Untuk melakukan penyuluhan, diperlukan sarana dan } \\
\text { prasarana yang memadai; tempat, audiovisual, dan alat bantu } \\
\text { penyebaran informasi, serta konsumsi, dana untuk ini bisa } \\
\text { diambilkan dari dana PKRS rumah sakit. } \\
\text { 3. Pembuatan leaflet tentang informasi HIV bisa menggunakan } \\
\text { dana rumah sakit yang sudah dialokasikan pada bidang PKRS } \\
\text { 4. Pengadaan kotak obat untuk pasien UPIPI yang adherence- } \\
\text { nya rendah. Dana bisa diambilkan dari PKRS atau NGO } \\
\text { 5. Pemberdayaan LSM dan pembentukan peer group tidak }\end{array}$ \\
\hline
\end{tabular}




\begin{tabular}{|c|c|c|}
\hline No. & Tahap & Keterangan \\
\hline & & $\begin{array}{l}\text { memerlukan pendanaan karena LSM memiliki dana tersendiri } \\
\text { untuk melakukan program kerja LSM. Jika LSM belum } \\
\text { memiliki program kerja tersebut, UPIPI bisa memberikan } \\
\text { masukan program ini, sehingga keberadaan LSM di UPIPI } \\
\text { lebih bermanfaat }\end{array}$ \\
\hline & $\begin{array}{l}\text { Tempat kegiatan } \\
\text { program }\end{array}$ & $\begin{array}{l}\text { 1. Penyuluhan atau konseling dilakukan di UPIPI } \\
\text { 2. Menyebarkan leaflet tentang informasi HIV dilakukan } \\
\text { dibagian screening Poli UPIPI, sekaligus memberikan edukasi } \\
\text { kepada pasien } \\
\text { 3. Pembagian kotak obat kepada pasien yang tingkat adheremce- } \\
\text { nya rendah dilakukan di bagian screening juga, karena di } \\
\text { situlah petugas paling lama berinteraksi dengan pasien, } \\
\text { sehingga petugas bisa menilai apakah pasien perlu dikasih } \\
\text { kotak obat atau tidak } \\
\text { 4. Pemasangan informasi HIV di website dan media sosial } \\
\text { RSUD Dr. Soetomo melalui tim pemasaran rumah sakit }\end{array}$ \\
\hline & $\begin{array}{l}\text { Bentuk promosi } \\
\text { program }\end{array}$ & $\begin{array}{l}\text { Pesan } \\
\text { 1. Penyampai pesan diutamakan dokter spesialis penyakit dalam } \\
\text { atau perawat UPIPI } \\
\text { 2. Perawat memberikan contoh simulasi penjadwalan minum } \\
\text { obat yang baik dan benar, sehingga meminimalisir pasien } \\
\text { untuk lupa minum obat } \\
\text { 3. Isi pesan diutamakan tentang manfaat dan cara kerja obat } \\
\text { ARV } \\
\text { Saluran Komunikasi } \\
\text { 1. Konseling dan penyuluhan } \\
\text { 2. Menggunakan internet } \\
\text { Media Promosi } \\
\text { 1. Leaflet } \\
\text { 2. Website } \\
\text { 3. Kotak obat }\end{array}$ \\
\hline & $\begin{array}{l}\text { Kebijakan yang } \\
\text { mendukung } \\
\text { program }\end{array}$ & $\begin{array}{l}\text { Menyusun peraturan: } \\
\text { 1. Setiap PPDS (sebagai pengganti dokter spesialis di UPIPI } \\
\text { yang memberikan pelayanan) selalu diberi tambahan ilmu } \\
\text { tentang konseling ART oleh dokter penanggung jawab UPIPI } \\
\text { 2. Membekali perawat baru yang masuk di Poli UPIPI dengan } \\
\text { ilmu tentang konseling ART } \\
\text { 3. Memberlakukan peraturan baru untuk selalu mengecek rekam } \\
\text { medis dari pasien datang hingga pasien pulang sehingga tahu } \\
\text { perjalanan pasien pada hari itu dan informasi yang seharusnya } \\
\text { diberikan kepada pasien lengkap } \\
\text { 4. Memperketat pencatatan dan pelaporan ART, sehingga } \\
\text { diketahui siapa saja pasien yang seharusnya datang namun } \\
\text { tidak datang }\end{array}$ \\
\hline & $\begin{array}{l}\text { Pihak yang bisa } \\
\text { bekerjasama }\end{array}$ & $\begin{array}{l}\text { 1. Meningkatkan kerja sama dengan rumah sakit sesama rujukan } \\
\text { ODHA untuk proses rujuk masuk dan keluar pasien, sehingga } \\
\text { posisi pasien terpantau dengan baik. Karena kemungkinan } \\
\text { pasien yang tidak datang pindah ke rumah sakit lain tanpa } \\
\text { memberitahukan kepada rumah sakit sebelumnya }\end{array}$ \\
\hline
\end{tabular}




\begin{tabular}{|c|c|c|}
\hline No. & Tahap & Keterangan \\
\hline & & $\begin{array}{l}\text { 2. Meningkatkan kerja sama dengan Dinas Kesehatan Provinsi } \\
\text { Jawa Timur dan Kota Surabaya untuk evaluasi ARV, misal } \\
\text { pada pelaporan rutin bulanan dan tahunan } \\
\text { 3. Meningkatkan efektivitas LSM dalam pendampingan dan } \\
\text { penjangkauan pasien yang belum mandiri di UPIPI } \\
\text { 4. Meningkatkan kerjasama dengan Puskemas wilayah tempat } \\
\text { tinggal pasien terkait keberadaan ODHA yang tidak kembali } \\
\text { ke UPIPI }\end{array}$ \\
\hline & Publik & $\begin{array}{l}\text { Internal Public } \\
\text { 1. Operational manager UPIPI sebagai penyusun program } \\
\text { 2. Tenaga medis Poli UPIPI sebagai pelaksana utama program } \\
\text { 3. Tenaga non medis Poli UPIPI sebagai tenaga pendukung } \\
\text { dalam pelaksanaan program } \\
\text { External Public } \\
\text { 1. Target audience pasien Poli UPIPI sebagai target utama } \\
\text { 2. Dinas Kesehatan Provinsi Jawa Timur dan Kota Surabaya } \\
\text { serta LSM sebagai pendukung program }\end{array}$ \\
\hline & $\begin{array}{l}\text { Bantuan dana } \\
\text { program }\end{array}$ & $\begin{array}{l}\text { 1. Mengupayakan dana rumah sakit, melalui PKRS dan Diklat } \\
\text { 2. Menggunakan dana dari NGO } \\
\text { 3. Bekerjasama dengan Dinas Kesehatan Provinsi Jawa Timur } \\
\text { dan Kota Surabaya }\end{array}$ \\
\hline \multirow[t]{2}{*}{8} & \multirow[t]{2}{*}{$\begin{array}{l}\text { Perencanaan } \\
\text { monitoring dan } \\
\text { evaluasi program }\end{array}$} & $\begin{array}{l}\text { Mengevaluasi 3-6 bulan sebelum program dimulai. } \\
\text { Input terdiri dari: } \\
\text { 1. Tenaga kesehatan yang akan memberikan } \\
\text { konseling dan penyuluhan sudah tepat } \\
\text { 2. Materi atau pesan yang akan dipublikasikan } \\
\text { sudah tertulis atau tercetak dengan benar } \\
\text { 3. Bahan dan media promosi sudah tersedia dan } \\
\text { siap digunakan atau dipublikasikan } \\
\text { 4. Provider kesehatan melakukan pekerjaannya } \\
\text { dengan benar sesuai fungsi dan jadwal }\end{array}$ \\
\hline & & $\begin{array}{l}\text { Memantau tiap pelaksanaan program, sejak } \\
\text { program diluncurkan sampai dengan } 3 \text { bulan } \\
\text { pertama dan kedua, dengan cara: } \\
\text { 1. Mengukur antusias pasien dengan } \\
\text { membandingkan jumlah pasien yang datang di } \\
\text { penyuluhan dengan yang ditargetkan } \\
\text { 2. Melakukan pretes dan postest secara acak untuk } \\
\text { melihat perubahan pengetahuan pasien sebelum } \\
\text { dan sesudah penyuluhan. Tujuannnya } \\
\text { mengetahui tingkat kemudahan atau kesulitan } \\
\text { pesan yang dipahami pasien } \\
\text { 3. Memastikan sumber daya (komunikator, media, } \\
\text { dan bahan promosi) tidak kekurangan pada saat } \\
\text { kegiatan } \\
\text { 4. Mengumpulkan input dari pasien mengenai } \\
\text { kendala pengaksesan produk, materi, dan media } \\
\text { yang digunakan, juga waktu dan tempat } \\
\text { pelaksanaan promosi }\end{array}$ \\
\hline
\end{tabular}




\begin{tabular}{|c|c|c|c|}
\hline \multirow[t]{4}{*}{ No. } & \multirow[t]{4}{*}{ Tahap } & \multicolumn{2}{|r|}{ Keterangan } \\
\hline & & Output & $\begin{array}{l}\text { Memantau perkembangan program tiap } 6 \text { bulan, } \\
\text { antara lain: } \\
\text { 1. Pelaksanaan program pemasaran sosial berjalan } \\
\text { sesuai jadwal } \\
\text { 2. Dana yang dibutuhkan mencukupi hingga akhir } \\
\text { kegiatan } \\
\text { 3. Jumlah sasaran penyuluhan sesuai target } \\
\text { 4. Mengukur respon (suka/ tidak atau bagus/ tidak) } \\
\text { dari publik terhadap media dan bentuk edukasi } \\
\text { pemasaran sosial } \\
\text { 5. Terjadi peningkatan adherence pasien yang } \\
\text { terpapar atau telah mendengar dan melihat } \\
\text { program pemasaran sosial } \\
\text { 6. Menyelesaikan hambatan, kendala, dan } \\
\text { penolakan yang muncul dari pasien } \\
\text { 7. Memperbaiki atau mengganti media dan bentuk } \\
\text { promosi jika respon yang didapatkan tidak baik }\end{array}$ \\
\hline & & Outcome & $\begin{array}{l}\text { 1. Mengukur tingkat paparan informasi pasien } \\
\text { sesudah } 3 \text { dan } 6 \text { bulan program berjalan } \\
\text { 2. Menganalisis data tingkat adherence pasien } \\
\text { pada laporan bulanan pasien }\end{array}$ \\
\hline & & Impact & $\begin{array}{l}\text { 1. Menganalisis kenaikan CD4 dan penurunan } \\
\text { Viraload pasien, dengan melihat laporan kohort } \\
\text { per } 12 \text { bulan } \\
\text { 2. Menganalisis penurunan jumlah pasien Poli } \\
\text { UPIPI yang rawat inap di UPIPI per } 12 \text { bulan } \\
\text { 3. Menganalisis penurunan jumlah pasien UPIPI } \\
\text { yang meninggal } 12 \text { bulan }\end{array}$ \\
\hline
\end{tabular}

Tabel 5.48 tersebut merupakan rencana social marketing yang disusun sesuai penelitian yang sudah dilakukan. Perencanaan social marketing ini berdasarkan tahapan dari Cheng, Kotler, dan Lee (2008) yang terdiri dari 10 tahap. Tahap ke-9 tidak dilakukan karena peneliti tidak sampai menjangkau tentang

\section{DAFTAR PUSTAKA}

American Marketing Association. 1999. Policy Compendium of the American Marketing Association. Chicago: American Medical Association

Andreasen, A. R.. 1994. Social Marketing Definition and Domain. Journal of Public Policy and Marketing. budgeting karena keuangan dan program di RSUD Dr. Soetomo sesuai dengan yang di-Musrembang-kan, dan tahap ke-10 tidak dilakukan juga karena tahap ini bisa disusun ketika rencana ini diterima tim manajemen UPIPI RSUD Dr. Soetomo Surabaya.

Andreasen, A. R.. 2001. Ethics in Social Marketing. Washington DC: Georgetown University Press.

Andreasen, A. R. 2004. Social marketing: Upstream and earlier. Presentation to the Innovations in Social Marketing conference, Austin, TX, April 20, 2004.

Baron, A. R. 2003. Psikologi Sosial Jilid 2 Edisi Sepuluh. Jakarta: Erlangga. 
Berry, S. 2006. Children, HIV and AIDS. avert.org. Diakses 20 April 2014.

Bloom dan Novelli. 1981. Problems and Challenges in Social Marketing. Journal of Marketing: Spring.

Bracher, M, Santow, G., dan Watkins, S.. 2004. Assessing the Potential of Condom Use to Prevent the Spread of HIV: A Microsimulation Study. Studies in Family Planning 35 (1):48-64.

Brigham, J. C. 1991. Social Psychology. New York: Harper Collins Publisher.

Courneya, K. S., dan McAuley, E. 1995. Cognitive mediators of the social influence - exercise adherence relationship: A test of the theory of planned behavior. Journal of Behavioral Medicine, 18, 499-515.

Cheng, Kotler, dan Lee. 2008. Social Marketing for Public Health: Global Trends and Success Stories. Boston: Jones and Barlet Publisher.

Council Health Management Team (CHMT). 2011. Adherence.

Dean, A.J., Walters, J., dan Hall, A. 2010. A Systematic Review of

Interventions to Enhance

Medication Adherence In

Children and Adolescents with

Chronic Illness. Pubmed Health.

Sitasi:

http://www.ncbi.nlm.nih.gov/pu

bmedhealth/PMH0030598/.

Diakses 10 November 2014.

Dinas Kesehatan Provinsi Jawa Timur (Dinkes Jatim). 2013. Analisis dan Situasi HIV AIDS Jawa TImur 2013. Surabaya: Dinkes Jatim.

Dinas Kesehatan Provinsi Jawa Timur (Dinkes Jatim). 2013. Presentasi Startegic of Using for ARV. Surabaya: Dinkes Jawa Timur.
Divisions of HIV AIDS Prevention. 2003. HIV and Its Transmission. Centers for Disease Control \& Prevention. Diakses 20 April 2014.

Fisher, J. D., Fisher W. A.. 1992. Changing AIDS-Risk Behaviour. Psycol Bull. 11: 455-474.

Fisher, J. D., Fisher W. A., Amico, K. R., Harman, J. J.. 2006. An Information-Motivation-

Behavioural Skills Model of Adherence to Antiretroviral Therapy. Health Psycol. 25:462-73.

Fithria, R. F., Purnomo A., Ikawati, Z. 2011. Faktor-faktor yang Mempengaruhi Tingkat Kepatuhan Pengobatan ARV (Antiretroviral) pada ODHA (Orang dengan HIV AIDS) di Rumah Sakit Umum Daerah Tugurejo dan Rumah Sakit Umum Panti Wilasa Citarum Semarang. Jurnal Manajemen dan Pelayanan Farmasi. Sitasi: http://jmpf.farmasi.ugm.ac.id/index .php/1/article/view/41. Diakses tanggal 21 Juni 2015.

Frederiksen, Lee. 1984. Marketing Health Behavior: Principle, Techniques, and Applications. Plenun Press. London

Giordano, et. al. 2012. Effect of a ClinicWide Social Marketing Campaign to Improve Adherence to Antiretroviral Therapy for HIV Infection. Springer Science+Business Media. LLC.

Haynes et al. 2002. Interventions for Helping Patients to Follow Prescriptions for Medications. Cochrane Database.

Kasali, R. 1998. Membidik Pasar Indonesia: Segmentasi, Targeting, dan Positioning. Jakarta: Gramedia Pustaka.

Kementerian Kesehatan RI. 2011. Pedoman Tatalaksana ARV. Jakarta: Kemenkes RI.

Kementerian Kesehatan RI. 2012. Pedoman Pelaksanaan Konseling 
dan Testing HIV (KT-HIV). Jakarta: Kemenkes RI.

Kementerian Kesehatan RI. 2014. Presentasi Early Warning Indicators of ARV. Jakarta: Kemenkes RI.

Kementerian Kesehatan RI. 2015. Pedoman Pencatatan dan Pelaporan HIV AIDS. Jakarta: Kemenkes RI.

Kementerian RI. Nomor 129. 2008. Strandar Pelayanan Minimal Rumah Sakit. Jakarta: Direktorat Jenderal Bina Pelayanan Medik.

Kementerian Kesehatan RI. Nomor 44. 2009. Rumah Sakit Umum. Jakarta: Direktorat Jenderal Bina Pelayanan Medik.

Keputusan Menteri Kesehatan (Kepmenkes) RI No. 782/MENKES/SK/IV/2011 tentang rumah sakit rujukan bagi orang dengan HIV dan AIDS

Kotler, P, dan Zaltman, G. 1971. Social marketing: An approach to planned social change. Journal of Marketing. 35, 3-12.

Kotler, P. 2003. Marketing Management. 11th edition. Prentice Hall.

Leavell, R. dan Schneider, A. 1997. Stimulating the private sector's participation in HIV IADS Specific Condom Marketing; Surabaya, Indonesia. SOMARC Occasional. Paper No. 22.

Mardiyalina, N. 2012. Faktor-faktor yang Mempengaruhi Ketaatan Kontrol pada Penderita HIV dengan ARV di Klinik Edelweis RS Gambiran Kota Kediri. Skripsi. Kediri: Sekolah Tinggi Ilmu Kesehatan Surya Mitra Husada.

McKenna, J., Guiterez, K., McCall, K. 2000. Strategies for Effective Youth Counter-marketing Program: Recommendations from Commercial Marketing Expert. Journal of Public Health Management and Practice.
Misovich, S.J., Martinez, T., Fisher, J.S., Bryan, A.D., dan Catapano, N. 2003. Predicting breast selfexamination: Test of the information-motivation-behavioral skills model. Journal of Applied Social Psychology.

Mihalko, S.L., Brenes, G.A., Farmer, D.F., Katula, J.A., Balkrishnan, R. and Bowen, D.J. 2004. Challenges and Innovations in Enhancing Adherence. Controlled Clinical Trials.

Munro, Salla, et. al.2006. A Review of Health Behaviour Theories: How Useful are these for Developing Interventions to Promote Longterm Medication Adherence for TB and HIV AIDS?. BMC Public Health. PubMed sitasi: http://biomedcentral.com/1472458/7/I04.

Niven, N. 1994. Psikologi Kesehatan pengantar untuk Perawat dan Profesional Kesehatan Lain. Jakarta: Buku Kedokteran EGC.

Notoatmodjo, S. 2002. Metodologi Penelitian Kesehatan. Jakarta: PT. Adi Mahasatya.

Notoatmodjo, S. 2005. Promosi Kesehatan dan Aplikasi. $1^{\text {st }}$ ed. Jakarta: PT. Rineka Cipta.

Panitia Akreditasi Rumah Sakit RSUD Dr. Soetomo. 2012. Panduan Akreditasi Rumah Sakit. Surabaya: PARS. RSUD Dr. Soetomo.

Polhaupessy, L.F. 2003. Behavior Therapy. Diktat Perkuliahan Psikoterapi. Bandung: Fakultas Psikologi Universitas Padjadjaran.

Ross E, dan Deverell, A. 2004. Psychosocial Approaches to Health, Illness and Disability: A Reader for Health Care Professionals. Pretoria: Van Schaik.

Rogers, RW. 1974. A Protection Motivation Theory of Fear Appeals and Attitude Change. Journal Psychology. 
Schwartz, Beverly; Middlestadt, Susan; and Cecelia Verzosa. 1994. Social Marketing Research on Educating Girls in Bangladesh. The Forum for Advanced Basic Education and Literacy, 3 (April), 8-9.

Soenaryo. 2002. Psikologi untuk Keperawatan. Jakarta: Buku Kedokteran EGC.

Solomon, D. 1989. A Social Marketing Perpective on Communication Campaigns. London: Sage.

Sue, S. and Young, J. 1998, Social Marketing as a Tool to Stop Child Abuse. Social Marketing Quarterly.

Stelzner, M. A. 2013. Social Media Marketing Industry Report. Social Media Examiner.

Strace, F., Massa A., Amico, K.R., dan Fisher, J.D. 2006. Adherence to Atiretroviral Therapy: An Empirical Test of the InformationMotivation-Behavioral skills Model. Health Psychology Vol 25.

Storey, J.D., Saffits, G.B., dan Rimon, J.G.. 2008. Social Marketing. Health Behavior and Health Education Theory, Research, and Practice. Jossey-Bass. www.josseybass.com.

Sugiharti, Yuniar Y., Lestary, H. 2014. Gambaran Kepatuhan Orang dengan HIV AIDS (ODHA) dalam Minum Obat ARV di Kota Bandung Provinsi Jawa Barat Tahun 2011-2012. Jurnal Kesehatan Reproduksi. Sitasi: http://ejournal.litbang.depkes.go.id/ index.php/kespro/article/view/3888 . Diakses tanggal 21 Juni 2015.

Supriyanto dan Ernawaty. 2008. Pemasaran Jasa Industri Kesehatan. Surabaya: Airlangga University Press (UAP).

Surat Keputusan Direktur RSUD Dr. Soetomo dan Dekan Fakultas Kedokteran Universitas Airlangga. 2013. Pembentukan Tim Medik AIDS. Surabaya: RSUD Dr. Soetomo.
Surat Keputusan Direktur RSUD Dr. Soetomo. 2013. Pembentukan Unit Perawatan Intermediete Penyakit Infeksi (UPIPI). Surabaya: RSUD Dr. Soetomo.

Surat Keputusan Menteri RI Nomor 44 Tahun 2009 tentang Rumah Sakit.

Surat Keputusan Menteri RI Nomor 129 Tahun 2008 tentang Standar Pelayanan Minimal Rumah Sakit.

The LifeWindows Project Team. 2006. The LifeWindows Information Motivation Behavioral Skills ART Adherence Questionnaire ( $L W$ $I M B-A A Q)$. Center for Health, Intervention, and Prevention. University of Connecticut. Sitasi: https://www.chip.uconn.edu/chipw eb/documents/Research/F_LWIMB ARTQuestionnaire.pdf. Diakses tanggal 25 Maret 2015.

Tim Monitoring dan Evaluasi Poli Paru. 2014. Data Monitoring dan Evaluasi TB. Surabaya: RSUD Dr. Soetomo.

Tim Monitoring dan Evaluasi UPIPI. 2014. Data Monitoring dan Evaluasi UPIPI; Early Warning Indicators (EWI's). Surabaya: RSUD Dr. Soetomo.

Tim Monitoring dan Evaluasi UPIPI. 2014. Data Monitoring dan Evaluasi UPIPI; Kohort HIV 2004 - 2014. Surabaya: UPIPI RSUD Dr. Soetomo.

Undang-undang Kesehatan RI No. 29 Tahun 2009 tentang Kesehatan

Weinreich. 2006. Hands-On Social Marketing: A Step-by-Step Guide to Designing Change for Good. Weinreich Communications.

World Health Organization. 2003. Adherence to Long-term Therapies: Evidence for Action. Genava. 2003. 
Upaya Social Marketing...(Lilis Masyfufah) 